\title{
Hematopoietik kök hücre nakli yapılan pediatrik olgularda paranazal sinüs bulgularının manyetik rezonans görüntüleme ile değerlendirilmesi
}

\begin{abstract}
Taner Arpacı
Dr. Öğretim Üyesi, Acıbadem Üniversitesi SHMYO, Acıbadem Adana Hastanesi Radyoloji Bölümü

$\ddot{0} \mathbf{z}$

Amaç: Hematopoietik kök hücre nakli (HKHN) yapılan pediatrik olgularda paranazal sinüslerde ortaya çıkan manyetik rezonans görüntüleme (MRG) bulgularının değerlendirilmesi. Yöntem: Kurumumuzda Şubat 2013-Haziran 2018 tarihleri arasında 228 pediatrik olguya HKHN yapıldı. Çeşitli nedenlerle hem nakil öncesi ve hem nakil sonrası baş-boyun MRG çekilmiş olan ve yaşları

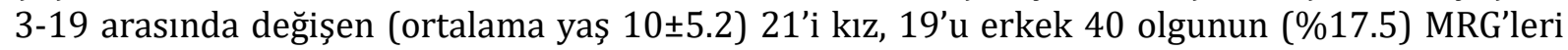
retrospektif olarak değerlendirildi. Normal havalanan sinüs 0 , sinüste mukozal kalınlaşma 1 , hava-sıvı seviyelenmesi 2 ve total havalanma kaybı 3 olarak skorlandı. Bulgular: Kırk olgunun 11'i (\%27.5) talasemi, dokuzu (\%22.5) akut lenfoblastik lösemi, altısı (\%15.0) akut myeloblastik lösemi, üçü (\%7.5) Hodgkin dişı lenfoma ve üçü (\%7.5) aplastik anemi nedeniyle takip edilmekteydi. Nakil öncesi 21 olgunun (\%52.5) MRG'si normaldi, 19 olguda (\%47.5) paranazal sinüslerde MRG bulgusu saptandı ve olgu bașına ortalama skor 1.55 olarak hesaplandı. Nakil sonrası 11 olgunun (\%27.5) MRG'si normaldi, 29 olguda (\%72.5) MRG bulgusu saptandı ve ortalama skor 3.57 idi. Nakilden önce MRG'si normal olan 21 olgunun 12'sinde (\%57.1) nakil sonrası MRG bulgusu ortaya çıktı. Nakilden önce MRG bulgusu saptanan 19 olgunun 11'inin (\%57.9) skoru arttı. Nakil öncesi ve sonrası MRG'lerde en sık mukozal kalınlaşma saptandı. Paranazal sinüslerde MRG bulgusu en sık maksiller sinüste ve en az frontal sinüste gözlendi. Sonuç: HKHN yapılan olgularda nakil öncesi görüntülemede paranazal sinüslerde MRG bulgularının varlığı nakil sonrası sinüzit riskini arttırabilir. Bu bulguların bilinmesi nakil sonrası ortaya çıkan sinüzitin daha doğru yönetilmesini ve olası ciddi komplikasyonların önlenmesini sağlayabilir.
\end{abstract}

Anahtar sözcükler: Hematopoietik kök hücre nakli, manyetik rezonans görüntüleme, paranazal sinüs, sinüzit.

\section{Magnetic resonance imaging of paranasal sinus findings in children following hematopoietic stem cell transplantation}

\begin{abstract}
Aim: The purpose of the study was to evaluate the magnetic resonance imaging (MRI) findings of paranasal sinuses, occurred in children after hematopoietic stem-cell transplantation (HSCT). Methods: From February 2013 to June 2018, 228 pediatric patients underwent HSCT. Forty (\%17.5) patients (21 girls, 19 boys; age range, 3-19 years; mean age 10 \pm 5.2 years) who underwent at least two head and neck MRI before and after HSCT were included in the study.

Yazının geliş tarihi: 26.11.2018 Yazının kabul tarihi: 13.12.2018

Sorumlu Yazar: Dr. Öğr. Üyesi Taner Arpaci, Acıbadem Üniversitesi SHMYO, Acıbadem Adana Hastanesi Radyoloji Bölümü, Cumhuriyet Caddesi, No: 66, Seyhan, Posta kodu: 01130, Adana, Eposta: tanerarpaci@yahoo.com, Cep tlf: 05333458351
\end{abstract}


MRI examinations were reviewed retrospectively. Normal sinus aeration was scored as 0 , mucosal thickening as 1, air-fluid level as 2 and complete loss of aeration as 3. Results: Eleven patients (\%27.5) were diagnosed as thalassemia, nine patients (\%22.5) as acute lymphoblastic leukemia, six patients (\%15.0) as acute myeloid leukemia, three patients (\%7.5) as nonHodgkin's lymphoma and three patients (\%7.5) as aplastic anemia. Before HSCT, 21 patients (\%52.5) had normal MRI, 19 patients (\%47.5) demonstrated MRI abnormalities and the mean score was 1.55. After HSCT, 11 patients (\%27.5) had normal MRI, 29 patients (\%72.5) showed MRI findings and the mean score was as 3.57. Twelve (\%57.1) of 21 patients who had normal pre-HSCT MRI developed MRI abnormalities after HSCT. Eleven (\%57.9) of 19 patients who showed abnormal pre-HSCT MRI demonstrated increased the mean score. The most common MRI finding was mucosal thickening, while they were most frequently observed in maxillary sinus and at least in frontal sinus. Conclusion: Presence of paranasal sinus abnormalities on pre-HSCT MRI might increase the risk of sinusitis after transplantation. Awareness of these findings might provide more appropriate management of sinusitis and prevention of possible serious complications after HSCT.

Key words: Hematopoietic stem-cell transplantation, magnetic resonance imaging, paranasal sinus, sinusitis

\section{Giriş}

Hematopoietik kök hücre nakli (HKHN) çeşitli hematolojik hastalıklarda potansiyel küratif tedavi seçeneği olarak giderek daha fazla uygulanmaktadır. Bununla birlikte nakil yapılan bireylerde fırsatçı enfeksiyonların insidansı gecikmiş immün yanıt, Graft-Versus-Host Hastalığ $(\mathrm{GVHH})$ ve immünsüpresif tedaviler nedeniyle daha sıktır. Son yıllarda HKHN komplikasyonlarının yönetiminde kaydedilen ilerlemelere rağmen, başarılı bir naklin önündeki en büyük engel hala enfeksiyonlardır. ${ }^{1,2}$ HKHN yapılan bireylerin 90\%'1 hastane sürecinde febril bir dönem geçirmekte ancak bunların sadece 40\%'ında kaynak belirlenebilmektedir. Paranazal sinüs hastalıkları bu hasta grubunda ateşin göz ardı edilen bir nedeni olabilmektedir. ${ }^{3}$ $\mathrm{Bu}$ hastalarda sinüzit ve rinit sik görülmektedir ve prevelansları \%30-51 olarak bildirilmiştir. 4,5

Yoğun kemoterapi, tüm vücut radyoterapisi, GVHH ve bunu tedavi etmek için verilen immünsüpresif ilaçlar, uzamış lökopeni ve tekrarlayan viral enfeksiyonlar HKHN sonrası sinüzit gelişmesini tetikleyen risk faktörleridir.5,6 Tanı, paranazal sinüslerin radyolojik bulgularına ve başağrısı, fasiyal ağrı, ateş ve pürülan rinore gibi semptomların varlığına göre koyulabilir. Bununla birlikte paranazal sinüzit, nakil sonrası olgularda intraorbital ve intrakranial sepsis gibi hayatı tehdit edici komplikasyonlara yol açabilir. Bu ciddi komplikasyonlar acil tanı ve tedavi gerektirir. ${ }^{1,7}$ Sinüzit tanısında görüntülemede öncelikle sinüs radyogramları ve bilgisayarlı tomografi (BT) önerilmektedir.3,8 Nötropenik ateşi olan olgularda paranazal sinüs görüntüleme bulgularının nakil öncesi çekilenlerle karşılaştırmalı olarak değerlendirilmesinin tanı ve tedavide daha faydalı olabileceği bildirilmiştir. ${ }^{4}$

Bu çalışmanın amacı, HKHN yapılan pediatrik olgularda nakil öncesi ve sonrası paranazal sinüslerde ortaya çlkan manyetik rezonans görüntüleme (MRG) bulgularının değerlendirilmesiydi.

\section{Yöntem}

Kurumumuzda Şubat 2013-Haziran 2018 tarihleri arasında çeşitli hematoonkolojik hastalıklar nedeniyle 228 pediatrik olguya HKHN yapıldı. Nakilden hem önce hem de sonra çeşitli nedenlerle baş-boyun MRG çekilmiş olan 49 olgu retrospektif olarak değerlendirildi.

Çalışmada 1.5 Tesla MRG cihazı (Siemens Magnetom Avanto Tim 76x18, Erlangen, Germany) kullanıldı. MRG tetkiklerinde T2 ağırlıklı turbo spin-echo (TSE) koronal imajlar (TR/TE: 3410/105 ms; kesit kalınlığı: 3 mm; FOV: 
$220 \times 100 \mathrm{~mm}$; matrix: $288 \times 320$ ) aynı radyolog tarafindan retrospektif olarak PACS (Picture Archiving Communication System, Centricity, GE Healthcare, Waukesha, WI) cihazında incelenerek sırasiyla sağ ve sol maksiller ve etmoid sinüsler, frontal ve sfenoid sinüsler, nazal kavite değerlendirildi. Normal havalanan hipointens sinyalli sinüs 0 , sinüs duvarında mukozal kalınlaşma 1 , sinüs lümeninde hava-sıvı seviyelenmesi 2 ve sinüste total havalanma kaybı 3 olarak skorlandı. Henüz havalanması gerçekleşmemiş sinüsler skorlanmadı. Ayrıca sinüs lümeninde submuköz retansiyon kisti olup olmadiğ , sinüslerde ve nazal kavitede invaziv fungal sinüzit bulgusu bulunup bulunmadığ ve nazal konka hipertrofisi gelişip gelişmediği değerlendirildi. Paranazal sinüste mukoza kalınlığının 2 mm'den geniş ölçülmesi mukozal kalınlaşma olarak kabul edildi. Nazal kavitede hava yolunu daraltan konka saptanması ve konka komşuluğundaki hava sütunu transvers çapının $1 \mathrm{~mm}$ 'nin altında ölçülmesi konka hipertrofisi olarak kabul edildi.

Olgularda baş ağrısı, ateș, nazal
konjesyon, rinore gibi sinüzit semptomlarının eşlik edip etmediği tıbbi kayıtlardan kontrol edildi. Bunun dışında HKHN yapılmasına neden olan hastalık tanısı, nakil tipi, hasta cinsiyeti, nakil sırasında hasta yaşı, nakil öncesi MRG ile HKHN ve HKHN ile nakil sonrası MRG arasındaki süreler gibi olası risk faktörleri araştırıldı. Paranazal sinüsleri ve nazal kaviteyi ilgilendiren malignite, radyoterapi, cerrahi ve biopsi hikayesi bulunan olgular, invaziv fungal sinüzit saptanan beş olgu ve paranazal sinüslerin havalanmasını etkileyen ekstramedüller hematopoez saptanan dört olgu çalışma dışında bırakıldı.

İstatiksel analiz için SPSS (statistic software, version 19.0 for Windows, IBM Company, Chicago, IL, USA) kullanıldı, risk faktörlerinin sinüzitle ilişkisini değerlendirmek için Paired Sample T test, Student $\mathrm{T}$ test ve Ki Kare testlerinden yararlanıldı. $\mathrm{p}<0.05$ değerleri istatistiksel olarak anlamlı kabul edildi. Takip edilen tüm prosedürler, insan deneyleri konusunda sorumlu komitenin etik standartları ve 1964 Helsinki Deklarasyonu ile uyumluydu. Hastalardan tıbbi onam alındı. Çalışma için etik kurul onayı alındı. Çalışmada çıkar çatışması yoktur ve finansal destek kullanılmamıştır.

\section{Bulgular}

Çalışmaya yaşları 3-19 arasında değișen (ortalama yaş $10 \pm 5.2$ ) ve çeşitli hemato-onkolojik hastalıkları bulunan ve kök hücre nakli yapılan 228 olgunun 40' (\%17.5) çalışmaya dahil edildi. Çalışmaya katılanların 21'i kiz (\%52.5), 19'u da (\%47.5) erkekti. Kırk olgunun 11'i (\%27.5) talasemi, dokuzu (\%22.5) akut lenfoblastik lösemi, altısı (\%15.0) akut myeloblastik lösemi, üçü (\%7.5) Hodgkin dışı lenfoma, üçü (\%7.5) aplastik anemi ve birer olgu (\%2.5) Hodgkin lenfoma, Ewing sarkom, rabdomyosarkom, osteopetrosis, Fankoni anemisi, orak hücreli anemi, agranulositoz ve immün yetmezlik tanılarıyla takip edilmekteydi. Kırk olgunun 32'sine (\%80.0) allojenik, altısına (\%15.0) otolog ve ikisine (\%5.0) haploidentik kök hücre nakli yapıldı.

HKHN öncesi 21 olgunun (\%52.5) MRG'si normaldi, 19 olguda (\%47.5) paranazal sinüsle ilgili radyolojik değişiklikler saptandı ve toplam skor 62, olgu başına ortalama skor ise 1.55 olarak hesaplandı. On iki olguda maksiller sinüslerde (\%30.0), 10 olguda etmoid sinüslerde (\%25.0), dokuz olguda (\%22.5) sfenoid sinüste ve altı olguda (\%15.0) frontal sinüste MRG bulgusu saptandı. Mukozal kalınlaşma 34 sinüste (Resim 1A), hava-sıvı seviyelenmesi 11 sinüste (Resim $1 \mathrm{~B}-\mathrm{C})$ ve total havalanma kaybı altı sinüste (Resim 1B) izlendi. Ayrıca üç olguda (\%7.5) maksiller sinüslerde submuköz retansiyon kisti ve 18 olguda (\%45.0) nazal konka hipertrofisi saptandı. 

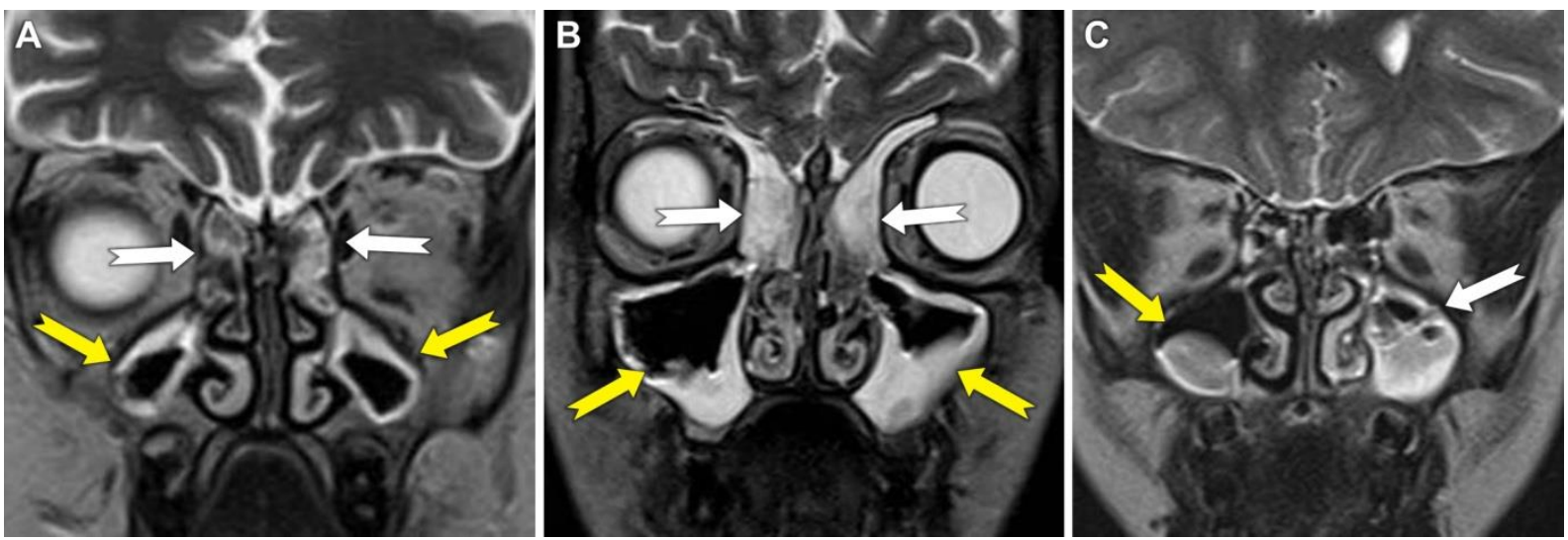

Resim 1. T2 ağırlıklı koronal MRG imajları (A) Akut lenfoblastik lösemi tanısıyla izlenen 8 yaşında erkek olguda bilateral maksiller (sarı oklar) ve etmoid sinüslerde (beyaz oklar) mukozal kalınlaşmalar izleniyor. (B) Orak hücreli anemi tanısıyla izlenen 14 yaşında kız olguda her iki maksiller sinüste hava-sıvı seviyelenmeleri (sarı oklar) ve bilateral ethmoid sinüsler ile frontal sinüste total havalanma kaybı (beyaz oklar) gözleniyor. (C) Hodgkin dıșı lenfoma tanısıyla izlenen 10 yaşında kız olguda sağ maksiller sinüste submuköz retansiyon kisti (sarı ok) ve sol maksiller sinüste hava-sıvı seviyelenmeleri (beyaz ok) mevcut.

HKHN sonrası 11 olgunun (\%27.5) MRG'si normaldi, 29 olguda (\%72.5) paranazal sinüsle ilgili radyolojik değișiklikler saptandı ve toplam skor 143, olgu başına ortalama skor ise 3.57 olarak hesaplandı. Yirmi beş olguda (\%62.5) maksiller sinüslerde, 21 olguda (\%52.5) sfenoid sinüste, 20 olguda (\%50.0) etmoid sinüslerde ve 11 olguda (\%27.5) frontal sinüste patoloji saptandı. Mukozal kalınlaşma 56 sinüste, hava-sıvı seviyelenmesi 12 sinüste ve total havalanma kaybı 28 sinüste izlendi. Ayrıca dokuz olguda (\%22.5) maksiller sinüslerde submuköz retansiyon kisti ve 34 olguda (\%85.0) nazal konka hipertrofisi saptandı (Tablo 1-2). Nakilden önce MRG'si normal olan 21 olgunun dokuzunun (\%42.8) MRG'si nakil sonrasinda da normalken, 12'sinde (\%57.1) nakil sonrası paranazal sinüsle ilgili radyolojik değişiklikler ortaya çlktı. Nakilden önce paranazal sinüslerde MRG bulgusu saptanan 19 olgunun 11'inin (\%57.9) skoru nakil sonrası arttı, beşinin (\%26.3) skoru değişmedi. Üç olguda (\%15.8) ise skor azaldı ve bunların ikisinde sıfıra düştü. Nakil öncesi çekilen ilk MRG ile HKHN arasındaki ortalama süre $127 \pm 108.4$ gün (11-324 gün) iken, HKHN ile nakil sonrası çekilen MRG arasındaki ortalama süre 208 \pm 147.2 gündü (27-542 gün). Hiç bir olguda sinüzit nedenli kemik invazyonu ve intraserebral veya intraorbital yayllım saptanmadı. Hiç bir olguya sinüzit nedeniyle cerrahi tedavi uygulanmadı. On altı (\%40.0) olgu nakil sonrası çeșitli nedenlerle ex oldu. Paranazal sinüs MRG bulguları ile hasta tanısı, nakil tipi, hasta yaşı ve cinsiyeti, süreler arasında anlamlı istatistiksel ilişki saptanmadi $(\mathrm{p}>0.05)$.

Tablo 1. Hematopoietik kök hücre nakli (HKHN) öncesi ve sonrası manyetik rezonans görüntüleme (MRG) bulguları. N: olgu sayısı (40), n: toplam sinüs sayısı (147)

\begin{tabular}{|c|c|c|c|c|}
\hline \multirow{2}{*}{$\begin{array}{l}\text { MRG } \\
\text { Bulguları }\end{array}$} & \multicolumn{2}{|c|}{ HKHN öncesi } & \multicolumn{2}{|c|}{ HKHN sonrası } \\
\hline & $\mathrm{N}-\mathrm{n}$ & $\%$ & $N-n$ & $\%$ \\
\hline$(-)$ & $\mathrm{N}: 21$ & 52.5 & $\mathrm{~N}: 11$ & 27.5 \\
\hline$(+)$ & $\mathrm{N}: 19$ & 47.5 & $\mathrm{~N}: 29$ & 72.5 \\
\hline $\begin{array}{l}\text { Mukozal } \\
\text { kalınlașma }\end{array}$ & n:34 & 23.1 & n:56 & 38.1 \\
\hline $\begin{array}{l}\text { Hava-sıvı } \\
\text { seviyesi }\end{array}$ & n:11 & 7.5 & $\mathrm{n}: 12$ & 8.2 \\
\hline $\begin{array}{l}\text { Total } \\
\text { havalanma } \\
\text { kaybı }\end{array}$ & $\mathrm{n}: 6$ & 4.1 & $\mathrm{n}: 28$ & 19.0 \\
\hline $\begin{array}{l}\text { Retansiyon } \\
\text { kisti }\end{array}$ & $\mathrm{N}: 3$ & 7.5 & $\mathrm{~N}: 9$ & 22.5 \\
\hline $\begin{array}{l}\text { Konka } \\
\text { hipertrofisi }\end{array}$ & $\mathrm{N}: 18$ & 45.0 & $\mathrm{~N}: 34$ & 85.0 \\
\hline
\end{tabular}


Tablo 2. Hematopoietik kök hücre nakli (HKHN) öncesi ve sonrası paranazal sinüslerde manyetik rezonans görüntüleme (MRG) bulgusu görülme sıklığı ve yüzdeleri (N: olgu sayısı)

\begin{tabular}{lllll}
\hline \multirow{2}{*}{$\begin{array}{l}\text { Paranazal } \\
\text { Sinüs }\end{array}$} & \multicolumn{2}{l}{ HKHN } & \multicolumn{2}{l}{ HKHN } \\
& öncesi & \multicolumn{2}{l}{ sonrası } \\
& N & $\%$ & N & $\%$ \\
\hline $\begin{array}{l}\text { Maksiller } \\
\text { Sinüs }\end{array}$ & 12 & 30 & 25 & 63 \\
Etmoid Sinüs & 10 & 25 & 20 & 50 \\
Frontal Sinüs & 6 & 15 & 11 & 28 \\
Sfenoid Sinüs & 9 & 23 & 21 & 53 \\
\hline
\end{tabular}

\section{Tartışma}

HKHN yapılan olgularda akut sinüzitin klinik ve radyolojik bulguları yeterli immün yanıt oluşmadı̆̆ için immünitesi sağlam bireylere göre değişkenlik ve tutarsızlık gösterebilmekte ve sinüzit tanısı zor koyulabilmektedir. ${ }^{4}$ Arulrajah ve ark. ${ }^{9}$ HKHN yapılan olgular ve immünitesi sağlam olguları karşılaştırdıkları çalışmada sinüzit semptomlarının sayısı ve radyolojik bulguların ciddiyeti arasında anlamlı farklılıklar buldular. Yaygın kullanılmasına rağmen literatürde, BT ve MRG'nin HKHN yapılan olgularda sinüzit tanısındaki değerini ölçen sadece birkaç çalışma vardır. ${ }^{3.10 .11}$ Billings ve ark. ${ }^{3}$ HKHN öncesi paranazal sinüs BT bulgularının nakil sonrası sinüzit gelişimiyle olan korelasyonunu 51 olguda retrospektif olarak araştırdılar. Nakil öncesi BT bulgularının varlığının ve ciddiyetinin nakil sonrası sinüzit gelişimiyle korelasyon gösterdiğini bildirdiler. Zamora ve ark. ${ }^{4}$ ise kendi sonuçlarına göre nakil öncesi BT bulgularının ne varlığının ne de ciddiyetinin sinüzit gelişimiyle istatistiksel olarak anlamlı ilişkisi bulunduğunu ve sonuçlarının bazı çalışmalarla uyumlu olduğunu belirttiler.1,12 Mukozal kalınlaşma dışında total veya subtotal havalanma kaybi ve hava-sıvı seviyesi gibi iki veya daha fazla paranazal sinüs bulgusunun varlığının spesifitesinin oldukça yüksek olduğunu bildirdiler. Mukozal kalınlaşmanın MRG'de genel popülasyonda prevelansı yüksek insidental bir bulgu olduğunu belirttiler. ${ }^{13,14}$ Yaptığımız çalışmada ise, Billings ve ark. ${ }^{3}$ ile uyumlu olarak nakilden önce MRG'si normal olguların 57\%'sinde nakil sonrası MRG'de paranazal sinüsle ilgili radyolojik değişiklikler ortaya çıkarken, nakilden önce paranazal sinüsle ilgili radyolojik değișiklikler saptanan olguların 89\%'unda nakil sonrası MRG bulgusu saptand,, 58\%'sinde ise skor artışı gözlendi ve genel ortalama skor ise $1.55^{\prime}$ den 3.57 'ye yükseldi $(\mathrm{P}<0.05)$. Zamora ve ark.'nın ${ }^{4}$ bulgularıyla uyumlu olarak nakil öncesi ve sonrası MRG'lerde paranazal sinüslerde en slk mukozal kalınlaşma saptandı. Nakil öncesi en az total havalanma kaybı izlenirken, nakil sonrası en az hava-sıvı seviyelenmesi gözlendi. Ayrıca Billings ve ark. (3) ile uyumlu olarak nakil öncesi ve sonrası en sık maksiller sinüste ve en az frontal sinüste bulgu saptandl. Won ve ark. (1) allojenik kök hücre nakli yapılan olgularda nakil sonrası sinüzit riskinin arttığını bildirdiler. Çalışmamızda nakil tipi ile sinüzit gelişme riski arasında istatistiksel olarak anlamlı fark saptanmadi. American College of Radiology çocuklarda komplike olmayan sinüzit tanısında rutin görüntülemeyi önermese de, dirençli, rekürren veya kronik sinüzitlerde özellikle intraorbital veya intrakranial komplikasyon şüphesi varlığında BT verimli olmaktadır. Çocuklarda BT'de kVp (kilovolt) ve mAs (miliamper saniye) değerleri azaltılarak radyasyon dozunun azaltılması önerilmektedir. ${ }^{15}$ Kurumumuzda HKHN yapılan olgularda paranazal sinüslerin değerlendirilmesi için iyonizan radyasyon içermemesi ve daha yüksek tanı değeri nedeniyle genellikle MRG tercih edilmektedir.

$\mathrm{Bu}$ çalışmanın kısıtlılıkları; retrospektif formatı, olgu sayısının görece azlığı, MRG'lerin farklı nedenlerle ve irregüler intervallerle çekilmiş olması, birçok olguda mikrobiyal ajanların tespit edilememiş olmasıydı.

Sonuç olarak; HKHN yapılan olgularda nakil öncesi görüntülemede 
paranazal sinüs bulgularının varlığı nakil sonrası sinüzit riskini arttırabilir. $\mathrm{Bu}$ bulguların nakil öncesinde bilinmesi nakil sonrası ortaya çıkan enfeksiyöz hastalıkların daha doğru değerlendirilmesini, sinüzit tanısının daha doğru koyularak uygun tedavinin verilmesini ve olası ciddi komplikasyonların önlenmesini sağlayabilir.

\section{Kaynaklar}

1. Won YW, Yi SY, Jang JH, Kim K, Kim SJ, Kim WS, Jung CW, Kim DH. Retrospective analysis of paranasal sinusitis in patients receiving hematopoietic stem cell transplantation. Int J Hematol 2011;93:383388.

2. Sullivan KM, Mori M, Sanders J, Siadak M, Witherspoon RP, Anasetti C, Appelbaum FR, Bensinger $\mathrm{W}$, Bowden $\mathrm{R}$, Buckner CD. Late complications of allogeneic and autologous marrow transplantation. Bone Marrow Transplant 1992;10 (Suppl 1):127-134.

3. Billings KR, Lowe LH, Aquino VM, Biavati MJ. Screening sinus CT scans in pediatric bone marrow transplant patients. Int $J$ Pediatr Otorhinolaryngol 2000;52:253-260.

4. Zamora CA, Oppenheimer AG, Dave H, Symons H, Huisman TA, Izbudak I. The role of screening sinus computed tomography in pediatric hematopoietic stem cell transplant patients. $J$ Comput Assist Tomogr 2015;39(2): 228-231.

5. Savage DG, Taylor P, Blackwell J, Chen F, Szydlo RM, Rule SA, Spencer A, Apperley JF, Goldman JM. Paranasal sinusitis following allogeneic bone marrow transplant. Bone Marrow Transplant 1997;19:55-59.

6. S. Yee, S.J. Stern, H.G. Hearnsberger, Suen JY. Sinusitis in bone marrow transplantation. Southern Med. J 1994;87: 522-524.

7. Drakos PE, Nagler A, Or R, Naparstek E, Kapelushnik J, Engelhard D, Rahav G, Neeman D, Slavin S. Invasive fungal sinusitis in patients undergoing bone marrow transplantation. Bone Marrow Transplant 1993;12:203-208.

8. S.S. Choi, G.J. Milmoe, P.A. Dinndorf, Quinones RR. Invasive aspergillus sinusitis in pediatric bone marrow transplant patients, Arch. Otolaryngol. Head Neck Surg 1995; 121: 1188-1192.

9. Arulrajah S, Symons H, Cahoon EK, Tekes A, Huisman TA, Izbudak I. Relationship between clinical sinusitis symptoms and sinus CT severity in pediatric post bone marrow transplant and immunocompetent patients. Eur J Pediatr 2012;171:375-381.

10. Sekine L, Manica D, Piltcher 0 . Rhinosinusitis in autologous and allogeneic bone marrow transplantation: a retrospective study on the performance of imaging studies on severity and prognostic evaluation. Rev Bras Hematol Hemoter 2010; 32:29-33.

11. Leite ED, Seber A, de Barbosa FG, Ginani VC, Carlesse FC, Gouvea RV, Zecchin VG, Carvalho CR, Szarf G, Lederman HM. Rapid, low-cost MR imaging protocol to document central nervous system and sinusabnormalities prior to pediatric hematopoietic stem cell transplantation. Pediatr Radiol.2011 Jun;41(6):749-756.

12. Thompson AM, Couch M, Zahurak ML, Johnson C, Vogelsang GB. Risk factors for post-stem cell transplant sinusitis. Bone Marrow Transplant 2002; 29:257-261.

13. Von Kalle T, Fabig-Moritz C, Heumann H, Vinkler P. Incidental findings in paranasal sinuses and mastoid cells: a cross-sectional magnetic resonance imaging (MRI) study in a pediatric radiology department. Rofo 2012;184:629-634.

14. Rak KM, Newell JD2, Yakes WF, Damiano MA, Luethke JM. Paranasal sinuses on MR images of the brain: significance of mucosal thickening. AJR Am J Roentgenol 1991; 156:381-384.

15. American College of Radiology. [Accessed September 26, 2014] ACR Appropriateness Criteria. 2014 May. 